\title{
Scrutinizing Environmental Protection Issue through a Case Study: An Evidence from Petrochemical Company
}

Zeittey Karmilla Bte Kaman

To Link this Article: http://dx.doi.org/10.6007/IJARBSS/v10-i11/8194

DOI:10.6007/IJARBSS/v10-i11/8194

Received: 05 September 2020, Revised: 01 October 2020, Accepted: 10 November 2020

Published Online: 26 November 2020

In-Text Citation: (Kaman, 2020)

To Cite this Article: Kaman, Z. K. B. (2020). Scrutinizing Environmental Protection Issue through a Case Study: An evidence from Petrochemical Company. International Journal of Academic Research in Business and Social Sciences. 10(11), 1176-1186.

\section{Copyright: @ 2020 The Author(s)}

Published by Human Resource Management Academic Research Society (www.hrmars.com)

This article is published under the Creative Commons Attribution (CC BY 4.0) license. Anyone may reproduce, distribute, translate and create derivative works of this article (for both commercial and non-commercial purposes), subject to full attribution to the original publication and authors. The full terms of this license may be seen at: http://creativecommons.org/licences/by/4.0/legalcode

Vol. 10, No. 11, 2020, Pg. 1176 - 1186

Full Terms \& Conditions of access and use can be found at http://hrmars.com/index.php/pages/detail/publication-ethics 


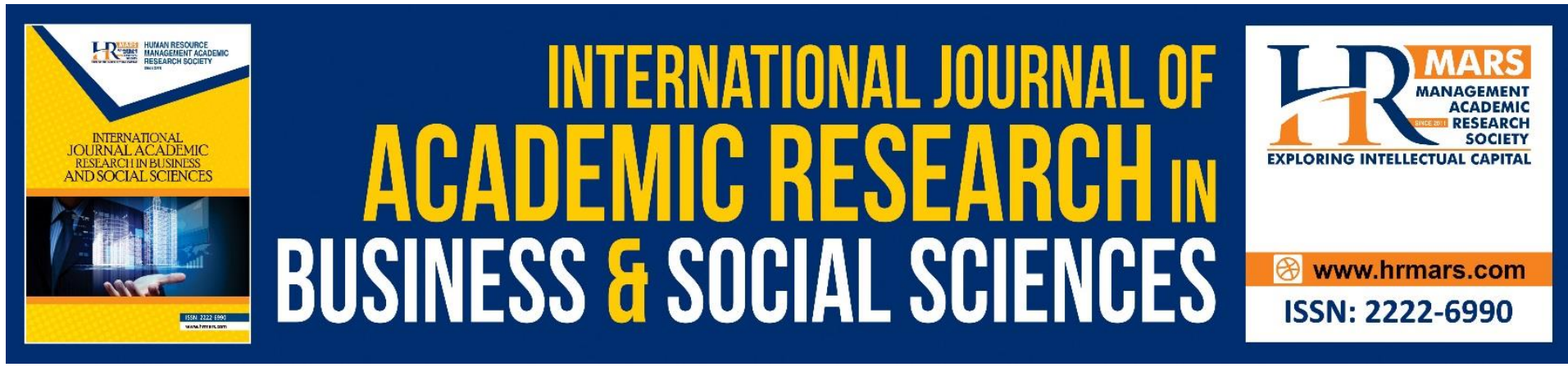

\title{
Scrutinizing Environmental Protection Issue through a Case Study: An evidence from Petrochemical Company
}

\author{
Zeittey Karmilla Bte Kaman \\ College of Business Management and Accounting \& Institute of Energy Policy and Research, \\ Universiti Tenaga Nasional \\ Email: Zeittey@uniten.edu.my
}

\begin{abstract}
This article discusses the use of case study method in the qualitative research paradigm by providing novel insights into the role of a petrochemical company towards environmental protection solution. A single case study was conducted in one of the leading petrochemical companies in Malaysia. A pseudonym is used to describe the company, which is referred to as 'Company $A$ '. The findings indicate that the current green corporate social responsibility (CSR) practice through EMS ISO14001 in Company $A$ is the answer to protect the environment as a respond to multiple stakeholders' demand nowadays.
\end{abstract}

\section{Introduction}

The rapid socio-economic growth and progress in Malaysia has given rise to tremendous environment impact (Hezri \& Hasan, 2006) on river (Tan \& Yap, 2006, and Al-Shami et al. 2010), which affects the aquatic environment of the country (Hajeb et al., 2012). Moreover, food and beverage, chemical and petrochemical, palm oil, textile, paper and rubber processing industries tend to be the major sources of industrial pollution in Malaysia (lyagba et al., 2008). Businesses not only give positive impact to the development of Malaysia but also give negative impact to the environment. However, it shows that the environmental harms brought by Malaysia manufacturing industry resulted in destructive effects towards economy, environment and social sustainability (Hassan et al. 2016). Proper implementation of green practices is needed in assisting companies towards corporate green sustainability initiative (Plan, 2015).

\section{Problem Statement}

Industries play a role in contributing to the alarming rate of pollution as they involve chemical in their operations. In January 2006 ammonia gas affected the residents of Kampung Sungai Gatom, Labis Johor when it was illegally dumped along the banks of Sungai Gatom. The ammonia gas was about 200 parts per million (ppm) within a radius of $200 \mathrm{~m}$, exceeding the safe level of less than $25 \mathrm{ppm}$. As a result, the Department of Environment (DOE) issued a directive notice under Section 31 of the Environmental Quality Act 1974 to the contractor and land owner involved in the dumping act. In September 2013, 4,000 litres of used engine oil 
was dumped into a Selangor river by the factories nearby and caused water supply disruptions to one million customers in the Klang Valley.Recently, in 24 July 2018 authorities ordered three plastic factories in Kuala Langat to close due to pollution (www.malaymail.com). Incidents like these prompt questions such as: "Why are these industries rampantly engaged in such an unethical conduct? Why are they harming people? What are the legitimate actions taken by the companies to protect the environment? Why do they not fulfil their socially responsibility towards protecting the environment?

To understand the current green CSR practices, the present study employed a case study method at one leading petrochemical company in Malaysia (known as company A).

\section{Research Question}

Through the literature review, the following research question is developed:

QI: How the company response to the environmental pollution issue with regards to green CSR practice?

\section{Research Method: A Single Case Study}

To answer question 1, qualitative methodology are most commonly applied when phenomena are insufficiently understood (Creswell, 2007). According to Corbin and Strauss (2008), qualitative research allows researchers to get at the inner experience of a participant, to determine how meanings are formed through and in a culture, and to discover rather than test variables. Case study method is defined as "A case study is an empirical inquiry that investigates a contemporary phenomenon in depth and within its real-life context, especially when the boundaries between phenomenon and context is not clearly evident" Yin 2009, p. 18).

\section{Case description: 'Company ' $A$ '}

A case study was conducted in one of the leading petrochemical companies in Malaysia. A pseudonym is used to describe the company, which is referred to as 'Company $A^{\prime}$. Below is the description of Company A profile:

\begin{tabular}{|l|l|}
\hline Background & $\begin{array}{l}\text { Established in 1997, Chemicals Group-wide Berhad } \\
\text { (later referred to as the group-wide entity) was } \\
\text { created with the objective of adding value to the } \\
\text { national natural gas resources and surplus hydrogen } \\
\text { for Malaysia. It is one of Malaysia's national oil } \\
\text { company subsidiaries and wholly-owned by the } \\
\text { Government. } \\
\text { Company A is part of the national, group-wide entity } \\
\text { conglomerate, serving as the leading integrated } \\
\text { producer of chemical products in Malaysia and one of } \\
\text { the largest in South East Asia. } \\
\text { Situated in the east coast of peninsular Malaysia, } \\
\text { Company A and their group-wide entity operate a } \\
\text { number of world class production sites, which are fully } \\
\text { vertically integrated from feedstock to downstream } \\
\text { end-products. }\end{array}$ \\
\hline
\end{tabular}




\begin{tabular}{|c|c|}
\hline & $\begin{array}{l}\text { Company A and the group-wide entity are ranked } \\
\text { amongst the largest companies in the world with a } \\
\text { proven track record in integrated oil and gas } \\
\text { operations. As one of a big conglomerate, Company A } \\
\text { and the group-wide entity is Malaysia's integrated } \\
\text { petroleum multinational corporation with a strong } \\
\text { ranking on the Fortune Global } 500^{\circledR} \text { with a presence in } \\
\text { more than } 30 \text { countries around the world. } \\
\text { Listed on Bursa Malaysia and with nearly three } \\
\text { decades of experience in the chemical industry, } \\
\text { Company A and the group-wide entity are established } \\
\text { with the objective to maximize the value from } \\
\text { Malaysia's natural gas resources and act as an } \\
\text { important manufacturer for chemical industry. The } \\
\text { parent company of Company A and the group-wide } \\
\text { entity first ventured into the production of certain } \\
\text { basic petrochemical products in the mid-1980s and } \\
\text { later embarked on several large scale petrochemical } \\
\text { projects with multinational joint venture partners. } \\
\text { Company A and the group-wide entity's joint venture } \\
\text { partners include The Dow Chemical Company, BASF } \\
\text { Netherlands BV, BP Chemicals, Idemitsu } \\
\text { Petrochemical Co Ltd, Mitsubishi Corporation, and } \\
\text { Sasol Polymers International Investments (Pty) Ltd. }\end{array}$ \\
\hline Product & $\begin{array}{l}\text { As the leading integrated chemical producer in } \\
\text { Malaysia with a total combined production capacity of } \\
\text { over } 10 \text { million metric tonnes per annum (mtpa), } \\
\text { Company A and the group-wide entity involve } \\
\text { primarily in manufacturing, marketing and selling a } \\
\text { diversified range of chemical products, including } \\
\text { ammonia commercially, as well as supplying carbon } \\
\text { monoxide (CO) and oxogas (a mixture of hydrogen and } \\
\text { CO), olefins, polymers, fertilisers, methanol and other } \\
\text { basic chemicals and derivative products. }\end{array}$ \\
\hline Activity & $\begin{array}{l}\text { Company A and the group-wide entity market a broad } \\
\text { range of chemical products to over } 30 \text { countries } \\
\text { globally with the key focus on South East Asia and the } \\
\text { Asia Pacific. Major markets outside Malaysia include } \\
\text { Indonesia, Philippines, Singapore, Thailand and } \\
\text { Vietnam as well as China, Japan, South Korea, Taiwan, } \\
\text { Australia, New Zealand and India. } \\
\text { The integrated development of Malaysia's } \\
\text { petrochemical industry is expected to promote the } \\
\text { development of the country's industrial base, } \\
\text { especially the plastics and chemical based component } \\
\text { manufacturing industry. The Company's consolidated } \\
\text { petrochemical business under Chemicals Group Wide }\end{array}$ \\
\hline
\end{tabular}




\begin{tabular}{|l|l|}
\hline Berhad is the largest integrated petrochemical \\
producer in Malaysia and among the largest in South \\
East Asia. \\
The Group also maintains its market reach with 60\% \\
revenue derived from outside Malaysia, particularly \\
Asia. The domestic market contributes to the \\
remaining 40\% of their revenue, further establishing \\
the leadership position as Malaysia's largest olefins \\
manufacturer and the sole producer of methanol and \\
urea. \\
Company A's operation comprises a diverse portfolio \\
of chemical products that are sold both domestically \\
and internationally. This company is a petrochemical \\
plant. \\
In 2012, Company A and the group-wide entity took \\
significant undertakings including large petrochemical \\
investments, the Refinery and Petrochemicals \\
Integrated Development (RAPID) project and Sabah \\
Ammonia Urea (SAMUR),the construction of the \\
Sabah Oil and Gas Terminal, Malaysia's first \\
regasification terminal, and two Floating Liquefied \\
Natural Gas projects. \\
In the 38 years of the group-wide entity stewardship, \\
the domestic oil and gas industry has become the \\
mainstay of the country's economy, contributing \\
approximately 15\% - 20\% of Malaysia's GDP. \\
As a leading integrated petrochemicals producer in \\
Malaysia and one of the largest in South East Asia, \\
Company A and the group-wide entity are the listed \\
holding entity for all parent company petrochemical \\
production, marketing and trading subsidiaries and \\
have a total combined production capacity of over 11 \\
million tonnes per annum. \\
In the last five years alone (2009-2013), the group- \\
wide entity has contributed an average of 41\% of total \\
revenue collected by the Government.
\end{tabular}

\section{Rationale for Choosing a Single Case Study at Company A}

Company $A$ was chosen as a case to be studied in the present research for five reasons, discussed below. Firstly, even a single case can contribute significantly contribution to knowledge and theory building. Previous studies have focused on examining the drivers for green purchase adoption among EMS 14001 certified companies in Malaysia (ElTayeb et al., 2010); perceived benefits derived from ISO14001 registrations for firms in a newly industrialized country like Malaysia (Tan, 2005); linking the adoption of an EMS ISO14001 with value-based thinking and sustainability (Sebhatu \& Enquist, 2007); describing the underlying structure of the ISO 14001 motives, difficulties and benefits and determining the respective latent constructs (Psomas et al., 2011; Papapavlou \& Satraki, 2013); investigating how a group 
of companies have developed a pattern to design a sustainability supply chain based on several requirements, including ISO 14001 (Chiarini, 2012); providing an immediate image about the reality of the EMS as experienced by Algerian certified ISO 14001 companies (Hariz \& Bahmed, 2013); and the effect of ISO 14001 on environmental regulatory compliance in China (McGuire, 2014).

By investigating current CSR practices (i.e. EMS ISO14001 internal process) in Company A towards environmental protection, the case study method has allowed the researcher to add to the existing literature and offered a model of CSR practices in a chemical company. Even though previous research has indicated the importance of EMS ISO14001 towards environmental protection (EP), very few focused on "how" EMS ISO14001 internal process leads to EP. Such study is very important so that the academics and practitioners benefit from the in-depth process employed at one leading petrochemical company in Malaysia.

Secondly, Company A was chosen because the case represented an extreme or unique case. Problem solving will only be found by investigating a single case study. This was achieved by examining the CSR green practices through EMS ISO14001 in Company A, which could not be possible if the study were to be conducted in any type of company. It was also noted that the growth of multinational companies operating all over the world has contributed to a growing demand for CSR especially on certain areas such as human rights and environment (Husted \& Allen 2006; and Arevalo \& Aravind, 2010).

Thirdly, a single case study was employed in Company A

because it was 'representative' of a 'typical case'. Company $A$ is one of the big conglomerates of 25 chemical companies in Malaysia. The governance, green practice and EP objective of Company $A$ and other group-wide entities are similar. Therefore, as mentioned by Yin (2009), Company A was 'representative' of a 'typical case'. Thus, the everyday circumstances in Company $A$ and group-wide entity could be said to be similar. Additionally, a manufacturing firm is typical of other manufacturing firms within the same industry. A chemical company that produces Ammonia, Carbon dioxide and Oxogas has therefore similar manufacturing activities. Furthermore, how Company A manages its scheduled wastes ethically represents its social responsibility towards EP in Malaysia.

Fourthly, the single case was conducted in Company A because it was a revelatory case. This situation existed when the researcher had an opportunity to observe and analyse a phenomenon previously inaccessible to scientific observation. The case study was therefore worth conducting because the "first hand" information would be revelatory. Consequently, the CSR implementation through EMS ISO14001 process could only be revealed when the researcher had the chance to do an in-depth interview, observation and detailed document analysis in Company $\mathrm{A}$.

Lastly, a single case involves a prolonged engagement and persistent observation in the field" (Creswell, 2007). During data collection process, the researcher managed to be engaged in field and made observation by doing the following:

1) Building trust with participants (e.g., refer to key informant no 1, no 2 and no 3 in Company A) 
2) Learning the organizational culture in Company A. The researcher observed how they worked and communicated with the employees. The researcher even participated in Company A's weekly meeting as well.

3) Checking for misinformation that could stem from distortions introduced by the researcher and informants. The way of doing this was by using a triangulation method (observation, interviews and document reviews).

4) Making decision about what was salient to the study, relevant to the purpose of the study, and of interest. For example, the researcher conducted three preliminary studies, and confirmed and validated the research framework with the key informants in Company $A$. Then during the in-depth interview sessions, the researcher only focused on understanding what was salient to the study only (e.g., EMS ISO14001 step-by-step process).

In all, the researcher took more than seven months conducting interviews, making observation and analysing the documents in Company $A$ to address the objectives of the study. Thus, Company A was deemed to be the most relevant in helping us understand the CSR practices and green process towards EP in Malaysia based on criteria described above. (see figure 1)

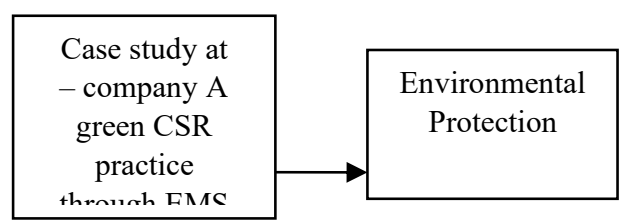

Figure 1: Green CSR practice in Company A

Source: Author

More importantly, previous researches have employed a case study method to understand the impact of business activities on the environment. For instance, Sambasivan and Fei (2008) did a case to evaluate the critical success factors of implementing ISO 14001 using analytic hierarchy process; Ardente et al. (2006) applied a case study methodology to examine the direct and indirect environmental effect on the life-cycle approach implemented within a small wine-producing firm; Cellura (2012) implemented a case study method on the environmental assessment of protected crops districts in the south of Italy; Pun and Hui (2001) adopted a qualitative case study methodology to understand and explain the procedural guideline of a seven step-by-step EMS ISO14001 approach to managing a construction practice; and Aiyub (2007) discussed ISO 14001 implementation in Malaysia's manufacturing sector on drivers, benefits, obstacles and implications. In short, a case study was adopted by previous scholars to gain novel insight of practical conduct of companies towards responsible green initiative on environmental protection.

\section{Results and Discussion}

Environmental Management System (EMS) ISO14001: Document-based Procedure and Practice

Figure 2 explains step by step EMS ISO 14001 practices in Company A which contribute to the environmental protection in Malaysia. The EMS is a management system put in place to protect the environment. Although the EMS subscribes to ISO 14001, which is a structured approach to address health, safety and environmental issues, this study solely focuses on the 
green practice on the environment. Because EMS ISO14001 is based on Company A's real practice, the process could be best described by key informant no 1 and key informant no 3 , as shown below:

Key informant no 1:

"...We can tackle all issues in a systematic approach. Meaning not every day we need to enforce the procedures. At the end, we do hope everybody will play their role, contribute to the system so it can run simultaneously with the company's objective on environmental protection..."

Key informant no 1:

"...So, the issue will be tackled in terms of a 'holistic approach', and more towards governance. Meaning, people do not have a chance to cheat, because all/every elements of the system (ISO 14001) have been audited and monitored. So it's all on cultivating voluntary responsibilities among employees..."

Key informant no 3:

"...By having EMS and certified bodies like SIRIM to monitor our system, we have to comply with the requirements and of the requirement are resources and responsibilities of the top management. By having that (EMS) we have a platform to support the management..."

Key informant no 3

"...EMS is directly related to ISO14001 standard and, yes, when we talk about EMS, it is actually related to understanding of ISO 14001 globally. Because it is a globally accepted system which controls or governs our environmental management system..."

The green practices implemented based on the documentation of EMS ISO14001 in environmental protection are captured as follows:

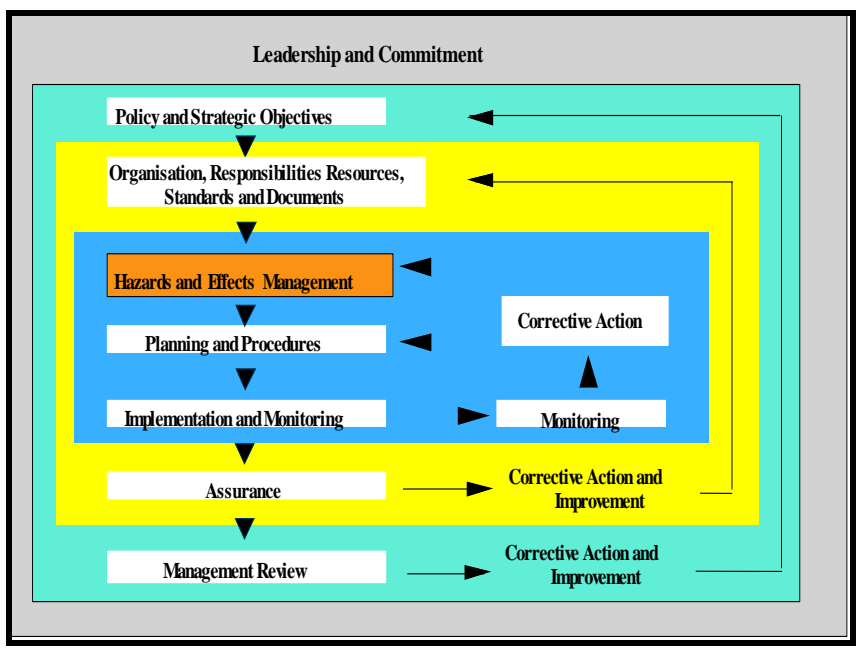

Figure 2: EMS ISO 14001 green practice in Company $A$ Source: Company A's documents

Figure 2 depicts the process of EMS ISO 14001 in Company A. This study focuses on scheduled wastes management as an example to explain the process involved. Company A embraces the EMS framework as the methodology to identify environmental hazards produced in its daily 
operations. Environmental hazards refer to effluents, emissions, schedule wastes, land pollution etc. This section onwards looks at the whole document of EMS ISO14001.

The cycle of activities can be understood as follows: (1) the company first commits to an environmental policy, then uses its policy as a basis to establish a plan, which sets the objectives and the targets to improve its environmental performance; (2) the next step is implementation. After that, the company; (3) evaluates its environmental performance to see whether the objectives and targets have been met; if (4) targets were not met, corrective action is taken. The result of this evaluation is then; (5) reviewed by top management to see if the said EMS framework is working. The Management later revisits the environmental policy and sets new targets in a revised plan. The company then implements the revised plan. The cycle repeats and continuous improvement occurs.

Key informant 1 later verified that EMS ISO14001 is a core activity of green practice of Company A:

"...EMS is improving the process from time to time because the nature of the product is risky so that's why we have undergone monitoring, auditing, and a certification process which is tight and comprehensive..."

\section{Conclusions}

In summary, a proactive effort towards reducing daily scheduled wastes emission at the plant leads Company A to strongly support company's environmental responsibility initiatives. This is done by engaging the Environmental Management System (EMS) ISO14001 framework that helps the company to achieve its environmental goals through consistent control of its operations. The assumption is that this increased control will improve the environmental performance of the company. The EMS itself does not dictate a level of environmental performance that must be achieved; each company that engages the EMS framework is free to tailor its business and goals to make profit and benefit the people and the planet at the same time. Thus, under EMS ISO 14001, the system encourages the company to continuously improve its environmental performance.

\section{Acknowledgment}

This research wishes to acknowledge the Universiti Tenaga Nasional (UNITEN) for the fund granted through the Bold 2025 Start-Up Grant Scheme No. RJO10289176/B/1/2017/6

\section{References}

Aiyub, K. A. (2007). ISO 14001 implementation in Malaysia's manufacturing sector: drivers, benefits, obstacles and implications. Doctoral dissertation, University of East Anglia. See also URL http://ethos.bl.uk/OrderDetails.do?uin=uk.bl.ethos.435976

Al-Shami, S. A., Rawi, C. S. M., HassanAhmad, A., \& Nor, S. A. M. (2010). Distribution of Chironomidae (Insecta: Diptera) in polluted rivers of the Juru River Basin, Penang, Malaysia. Journal of Environmental Sciences, 22(11): 1718-1727.

Ardente, F., Beccali, G., Cellura, M., \& Marvuglia, A. (2006). POEMS: a case study of an Italian wine-producing firm. Environmental management, 38(3): 350-364.

Arevalo, J. A., \& Aravind, D. (2010). The impact of the crisis on corporate responsibility: the case of UN global compact participants in the USA. Corporate Governance: The international journal of business in society, 10(4): 406-420. 
Cellura, M., Ardente, F., \& Longo, S. (2012). From the LCA of food products to the environmental assessment of protected crops districts: a case-study in the south of Italy. Journal of environmental management, 93(1), 194-208.

Chiarini, A. (2012). Designing an environmental sustainable supply chain through ISO 14001 standard. Management of Environmental Quality. 24(1): 16 - 33

Corbin, J., and Strauss, A. (2008). Basics of Qualitative Research: Techniques and Procedures for Developing Grounded Theory (3rd ed.). Thousand Oaks, CA: Sage Publications

Creswell, J. W. (2007). Qualitative Research Inquiry and Research Design: Choosing Among Five Approaches. Second Edition. Thousand Oaks, California: Sage

ElTayeb, T. G., Zailani, S., and Jayaraman, K. (2010). The examination on the drivers for green purchasing adoption among EMS 14001 certified companies in Malaysia. Journal of Manufacturing Technology Management. 21(2): 206 - 225.

Hariz, S., and Bahmed, L. (2013). Assessment of environmental management system performance in the Algerian companies certified ISO 14001. Management of Environmental Quality: An International Journal. 24(2): 228 - 243.

Hassan, M. G., Abidin, R., Nordin, N., \& Yusoff, R. Z. (2016). GSCM practices and sustainable performance: A preliminary insight. Journal of Advanced Management Science, 4 (5): 430-434

Hezri, A. A., and Hassan, M. N. (2006). Towards sustainable development? The evolution of environmental policy in Malaysia. Natural Resources Forum. (30): 37-50.

Hajeb, P., Jinap, S., Ismail, A., Fatimah, A.B., Jamilah J. and Rahim, M.A. 2009. Assessment of mercury level in commonly consumed marine fishes in Malaysia. Food Control. 20(1): 7984.

Husted, B. W., \& Allen, D. B. (2006). Corporate social responsibility in the multinational enterprise: Strategic and institutional approaches. Journal of international business studies, 37(6): 838-849.

lyagba, M. A., Adoki, A., and Sokari, T. G. 2008. Testing biological methods to treat rubber effluent. African Journal of Agricultural Research. 3(6): 448-454.

Lozano, F. J., Freire, P., Guillén-Gozalbez, G., Jiménez-Gonzalez, C., Sakao, T., Mac Dowell, N., ... \& Viveros, T. (2016). New perspectives for sustainable resource and energy use, management and transformation: approaches from green and sustainable chemistry and engineering. Journal of Cleaner Production, (30): 1-3.

McGuire, W. (2014). Analysis The effect of ISO 14001 on environmental regulatory compliance in China. Ecological Economics. (105) : 254-264.

Plan, E. M. (2015). Chapter 6: Pursuing green growth for sustainability and resilience. In. Polonsky, M. J. (2011). Transformative green marketing: Impediments and opportunities. Journal of Business Research, 64(12): 1311-1319.

Sebhatu, P. S., \& Enquist, B. (2007). ISO 14001 as a driving force for sustainable development and value creation. The TQM Magazine, 19(5): 468-482.

Papapavlou, A., \& Satraki, M. (2013). Language of advertising in bidialectal settings: Does the code matter? Multilingual Academic Journal of Education and Social Sciences, 1(2), 1339.

Psomas, E. L., Fotopoulos, C. V., \& Kafetzopoulos, D. P. (2011). Motives, difficulties and benefits in implementing the ISO 14001 Environmental Management System. Management of Environmental Quality: An International Journal, 22(4): 502-521.

Pun, K. F., \& Hui, I. K. (2001). An analytical hierarchy process assessment of the ISO 14001 environmental management system. Integrated Manufacturing Systems, 12(5): 333-345. 
Sambasivan, M., \& Fei, N. Y. (2008). Evaluation of critical success factors of implementation of ISO 14001 using analytic hierarchy process (AHP): a case study from Malaysia. Journal of cleaner production, 16(13): 1424-1433.

Tan, L. P. (2005). Implementing ISO 14001: is it beneficial for firms in newly industrialized Malaysia?. Journal of Cleaner Production, 13(4): 397-404.

Tan, S. G., \& Yap, C. K. (2006). Biochemical and molecular indicators in aquatic ecosystems: current status and further applications in Malaysia. Aquatic Ecosystem Health \& Management, 9(2): 227-236.

Yin, R. K. (2009). Case study research: Design and methods. 4th ed. Thousand Oaks, CA: Sage Publications. 